a. Division of Inborn Errors of Metabolism, Hospital "Prof. Dr. Juan P. Garrahan"

b. Division of Pediatric Neurology Mucopolysaccharidosis Clinic, Hospital Universitario Austral, Pilar, Buenos Aires.

c. Pediatric Ophthalmology,

Universidad Católica Argentina.

d. Genetic Medicine Division

Hospital de Niños "Dr. Ricardo

Gutiérrez", Autonomous City of

Buenos Aires.

e. Hospital Privado de Córdoba.

f. Pediatric Airway Endoscopy,

Pediatric Airway Endoscopy

Hospital "Prof
Garrahan".

g. Cardiology Division, Hospital de Niños "Dr. Ricardo Gutiérrez".

h. Division of Audiology; Ear, Nose and Throat Department, Hospital de Niños "Dr. Ricardo Gutiérrez"

Division of Pediatric

Rheumatology, Service of

Clinical Pediatrics, Department of

Pediatrics of Hospital Italiano de Buenos Aires.

j. Department of Hematology,

Hospital de Niños "Dr. Ricardo Gutiérrez" and Fundación

Favaloro.

k. Department of Pediatric

Rheumatology, Hospital de Niños "Dr. Ricardo Gutiérrez".

1. Dr. Ricardo Gutiêrrez".

Metabolism, Hospital "Prof. Dr. Juan P. Garrahan".

11. Coordinator at the Multipurpose

Day Hospital, Hospital de Niños Day Hospital, Hospit
"Ricardo Gutiérrez"

m.Department of Growth and

m.Department of Growth and
Development, Hospital "Prof. Dr. Juan P. Garrahan".

n. Department of Metabolic

Disorders, Clínica Universitaria Reina Fabiola.

ñ. Respiratory Diseases Center, Hospital de Niños "Dr. Ricardo Gutiérrez"

o. Division of Pediatric and Adult Allergy, Hospital Italiano de Buenos Aires. Coordinator of the Food Allergy Task Force, Internation Institute (ILSI) Argentin Growth and Development

p. Growth and Development, referra center in the field of Inborn Er Hospital Pediátrico "Dr. H. J. Notti Hospital Pediátrico "Dr. H. J. Notti Mendoza".

q. Spinal Disease, Hospital "Prof. Dr. Juan P. Garrahan

Dr. Chamoles Laboratory.

s. Unit of Metabolism, Hospital Sor María Ludovica, La Plata.

. Department of Bone Marrow

Transplant, Hospital “Prof. Dr. Juan P. Garrahan".

u. Neurosurgery, Universidad de Buenos Aires (UBA), Department of Neurosurgery, Hospital "Prof. Dr. Juan P. Garrahan," Past President of the International Society of Pediatric Neurosurgery (ISPN), awarded with the Latin American Federation of of Neurosurgical Societies (Federacion Latinoamericana FLANC) medal of honor in 2018

E-mail address:

Luisa Bay, M.D.: bay.luisa@gmail.com

Funding: None.

Conflict of interest:

Doctors Luisa Bay, Norberto Guelbert, Alejandro Fainboim, Norma Spécola, Guillermo Drelichman, and Marcela Pereyra have received professional fees from Sanofi for conducting teaching activities about lysosomal storage diseases.

Received: 7-21-2020 Accepted: 10-20-2020

\title{
New recommendations for the care of patients with mucopolysaccharidosis type I
}

\author{
Luisa Bay, M.D. ${ }^{a}$, Hernán Amartino, M.D. ${ }^{b}$, Alejandra Antacle, M.D. ${ }^{c}$, \\ Claudia Arberas, M.D. ${ }^{d}$, Adriana Berretta, M.D. ${ }^{e}$, Hugo Botto, M.D.f, \\ Mariana Cazalas, M.D. ${ }^{g}$, Adriana Copiz, B.S. ${ }^{h}$, Carmen De Cunto, M.D. ${ }^{i}$, \\ Guillermo Drelichman, M.D. ${ }^{j}$, Graciela Espada, M.D. ${ }^{k}$,Hernán Eiroa, M.D. ${ }^{l}$, \\ Alejandro Fainboim, M.D. ${ }^{l l}$, Virginia Fano, M.D. ${ }^{m}$, Norberto Guelber, M.D. ${ }^{n}$, \\ Alberto Maffey, M.D. ${ }^{\tilde{n}}$, Claudio Parisi, M.D. ${ }^{\circ}$, Marcela Pereyra, M.D. ${ }^{p}$,

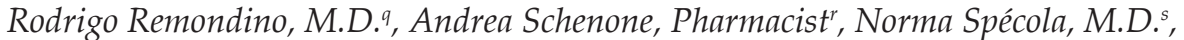 \\ Raquel Staciuk, M.D. ${ }^{t}$ and Graciela Zuccaro, M.D. ${ }^{u}$
}

\begin{abstract}
Considering the advances made on mucopolysaccharidosis type I after the consensus study published by a group of experts in Argentina in 2008, recommendations about genetic testing, cardiological follow-up, airway care, hearing impairment detection, spinal and neurological conditions, as well as current treatments, were reviewed. Emphasis was placed on the need for early diagnosis and treatment, as well as an interdisciplinary follow-up.

Key words: mucopolysaccharidosis type I, classification, treatment, diagnosis, follow-up.
\end{abstract}

http: / / dx.doi.org/10.5546/ aap.2021.eng.e121

To cite: Bay L, Amartino H, Antacle A, Arberas C, et al. New recommendations for the care of patients with mucopolysaccharidosis type I. Arch Argent Pediatr 2021;119(2):e121-e128

\section{INTRODUCTION}

In 2008, a consensus study was published about the diagnosis and treatment of mucopolyssacharidosis type I (MPS I) in Argentina. ${ }^{1}$ Time elapsed regarding the treatment and follow-up in our setting and in the world underscores the need to review the recommendations about some aspects of the disease.

\section{Clinical forms}

MPS I patients were classified according to the degree of severity into three clinical forms: Hurler, HurlerScheie, and Scheie. At present, this disease has been classified into severe form (SF), formerly called Hurler syndrome, and attenuated form (AF), which comprises the Hurler-Scheie and Scheie syndromes. ${ }^{1}$

\section{Genetics}

MPS I is an autosomal recessive disease whose genetic heterogeneity partly accounts for its clinical heterogeneity. The responsible gene is IDUA, which contains 14 exons and is localized on the 4p16.3 chromosomal locus. Today, close to 100 mutations are known, and 20 of them are involved in $85 \%$ to $90 \%$ of cases.

In $90 \%$ to $95 \%$ of the cases, the mutations are identified by complete sequencing, since it is not possible to identify them using simpler techniques. There are missense (AF), nonsense (SF), and deletion mutations.

In the SFs, the most frequent mutations are W402X (45\%) and Q70X (16\%), both in homozygosity. In the AFs, heterozygous variants combined with one of them may be found.

The clinical form cannot be determined by enzyme assays or biochemical markers. The genotypephenotype correlation may be especially helpful in newborn infants.

Out of 538 MPS I cases in the international registry, $67.6 \%$ of the 380 SFs had mutations that allowed predicting the phenotype. ${ }^{2}$ Every diagnosed patient should receive genetic counseling.

\section{Cardiovascular assessment}

Between $88 \%$ to $93 \%$ of the patients with SFs and AFs have cardiac manifestations ${ }^{3,4}$ (Table 1). Available treatments prolong survival, but coronary heart disease and valve 
diseases occur despite treatment ${ }^{5,6}$ causing a high morbidity and mortality. Fifty percent of patients with the SF die because of a cardiac cause. ${ }^{7-9}$

Valve abnormalities were reported in $35 \%$ of Latin American patients with the SF and $54 \%$ with the AF, versus $73 \%$ and $87 \%$ in the rest of the world. This difference might be related to a regional phenotype or to the way the diagnostic assessment is performed. ${ }^{10}$

The following is recommended for cardiological diagnosis and management:

- Cardiovascular examination, electrocardiogram (for abnormal heart rhythm) and baseline echocardiograms.

- In the follow-up: ${ }^{11-13}$ Echocardiogram every 1 to 2 years if there are no abnormalities or if these are mild. Every 6 months or more frequently when there are moderate to severe conditions.
- Holter monitoring, only indicated for palpitations or ECG picked-up arrhythmias.

- Cardiopulmonary exercise testing; difficult to perform due to skeletal abnormalities; no studies support its use.

- For suspected coronary artery disease, multislice computed tomography, myocardial perfusion, and CT angiogram or MR angiography are performed when the disease of great vessels is suspected.

- In the future, it will be necessary to determine the vascular risk, calculating the vascular age with a Doppler echocardiogram of the neck vessels and the pulse wave velocity. ${ }^{11}$

\section{Airway assessment}

Large airway obstruction is a serious problem..$^{14}$ The hypertrophy of palatine tonsils and adenoids results in snoring, obstruction, and

TABLE 1. Most important cardiac manifestations

\begin{tabular}{|c|c|c|c|c|}
\hline $\begin{array}{l}\text { Cardiac } \\
\text { condition }\end{array}$ & Frequency & Manifestation & $\begin{array}{l}\text { Diagnosis } \\
\text { and follow-up }\end{array}$ & $\begin{array}{l}\text { Modifications } \\
\text { with treatment }\end{array}$ \\
\hline $\begin{array}{l}\text { Mitral/aortic } \\
\text { valve disease }\end{array}$ & $\begin{array}{l}\text { Mitral valve } \\
\text { disease is more } \\
\text { frequent. }\end{array}$ & $\begin{array}{l}\text { Regurgitation } \\
\text { and stenosis. }\end{array}$ & $\begin{array}{l}\text { Echocardiogram (57\% } \\
\text { has normal auscultation). } \\
\text { Concerning patients with } \\
\text { attenuated forms, } 14 \% \text { would } \\
\text { require valve replacement. }\end{array}$ & $\begin{array}{c}\text { HSCT and ERT } \\
\text { neither modify } \\
\text { nor stop progression. }\end{array}$ \\
\hline $\begin{array}{l}\text { Myocardial } \\
\text { involvement }\end{array}$ & $\begin{array}{l}\text { Very frequent } \\
\text { in severe forms. }\end{array}$ & $\begin{array}{l}\text { Hypertrophy }(83 \%) \text {. } \\
\text { Dilated cardiomyopathy. } \\
\text { Diastolic dysfunction } \\
\text { in } 50 \% .\end{array}$ & $\begin{array}{c}\text { Echocardiogram. } \\
\text { Electrocardiogram: } \\
\text { hypertrophy is not shown } \\
\text { due to the low conductivity } \\
\text { of glycosaminoglycans. }\end{array}$ & $\begin{array}{c}\text { HSCT and ERT improve } \\
\text { hypertrophy and } \\
\text { ventricular function. }\end{array}$ \\
\hline $\begin{array}{l}\text { Coronary } \\
\text { involvement }\end{array}$ & $\begin{array}{l}\text { Less frequent than } \\
\text { in other } \\
\text { mucopolysaccharidosis. }\end{array}$ & $\begin{array}{c}\text { Diffuse compromise } \\
\text { with ischemia leading } \\
\text { to a dilated } \\
\text { cardiomyopathy. }\end{array}$ & $\begin{array}{c}\text { Multislice CT and myocardial } \\
\text { perfusion for the diagnosis. } \\
\text { Electrocardiogram: } \\
\text { no evidence of ischemia. }\end{array}$ & $\begin{array}{c}\text { The effect of the HSCT and } \\
\text { ERT on the coronary lesion } \\
\text { ill depend on the previous } \\
\text { w severity of this condition. } \\
\text { Other publications state } \\
\text { that this does not have } \\
\text { an influence. }\end{array}$ \\
\hline $\begin{array}{l}\text { Arterial D } \\
\text { involvement }\end{array}$ & $\begin{array}{l}\text { Dilation of the aortic root in } \\
38 \% \text { of the severe forms. } \\
\text { Arterial hypertension } \\
\text { in } 32 \% \text { of patients. }\end{array}$ & $\begin{array}{c}\text { in Attenuated types } \\
\text { of stenosis. } \\
\text { Lower limb pain } \\
\text { and claudication. } \\
\text { HTN: involvement } \\
\text { of the renal arteries. }\end{array}$ & $\begin{array}{c}\text { BP monitoring. } \\
\text { Clinical suspicion. } \\
\text { Echocardiogram and arterial } \\
\text { Doppler ultrasound. }\end{array}$ & No data available. \\
\hline $\begin{array}{l}\text { Pulmonary } \\
\text { hypertension }\end{array}$ & Rare. & $\begin{array}{l}\text { Dyspnea. } \\
\text { High morbidity } \\
\text { and mortality. }\end{array}$ & Echocardiogram. & No data available. \\
\hline $\begin{array}{l}\text { Endothelial } \\
\text { dysfunction }\end{array}$ & $\begin{array}{l}\text { Increased risk } \\
\text { in MPS I. }\end{array}$ & $\begin{array}{l}\text { In adolescents and } \\
\text { e-adolescents, vascular age } \\
\text { is equivalent to that of } \\
\text { a } 40 \text {-year-old individual. }\end{array}$ & $\begin{array}{c}\text { Neck-vessel } \\
\text { Doppler ultrasound. }\end{array}$ & $\begin{array}{l}\text { Decreases with ERT } \\
\text { and HSCT although } \\
\text { endothelial function } \\
\text { is not recovered. }\end{array}$ \\
\hline
\end{tabular}

HSCT: hematopoyetic stem cell transplantation; ERT: enzyme replacement therapy; HTN: arterial hypertension; BP: blood pressure; MPS I: mucopolysaccharidosis type I. 
obstructive sleep apneas. They should be studied with sleep polysomnography and lateral neck $\mathrm{X}$-ray in sniffing position. ${ }^{15,16}$

Tonsillectomy and adenoidectomy improve ventilation and the deleterious effect of nocturnal hypoxia on the central nervous system (CNS) and other organs. It should be done carefully because of possible cardiac complications, added to the presence of subglottic infiltrates. ${ }^{17}$

With increasing age, scoliosis and thoracic stiffness develop, together with restrictive ventilatory impairment. Glycosaminoglycan accumulation on the tracheal and bronchial walls worsens the obstructive ventilatory impairment, so a tracheostomy may be required.$^{18}$ Lung interstitial infiltration in the newborn infant has been described. ${ }^{19}$ Difficult airways should be evaluated before surgery, as a tracheostomy can prevent post-operative complications. ${ }^{20,21}$

\section{Audiological evaluation}

Recurrent diseases of the middle ear are frequent and early. Repeated abnormal hearing screening tests might lead to the suspicion of mucopolysaccharidosis. If there is progressive hearing loss, it should be re-assessed at 6, 9, and 12 months.

Hearing loss is of conductive or mixed type and some cases progress to neurosensorial type. Glycosaminoglycan deposits occur first in the tympanic membrane, then in the inner ear, and finally at a central level.

When there is a moderate to severe conductive hearing impairment, the ear canal must be stimulated to preserve the quality of communication. Severe conduction impairment no longer has an indication for treatment.

The indication for hearing aids, cochlear and osseointegrated implant processors depends on the patient's hearing level and overall commitment. An audiological evaluation should include subjective or behavioral tests for the diagnostic confirmation. ${ }^{22}$

\section{Spinal health}

An anterior and medial defect of the vertebral body, the classic platyspondyly aspect with the presence of an anterior peak or notch, because of an incomplete endochondral ossification of the vertebral body, ${ }^{23,24}$ trapezoid- or wedged-shaped vertebrae,${ }^{23}$ large intervertebral discs in relation to the hypoplastic vertebrae, the presence of a posterior intracanal bulging, ${ }^{26,27}$ and spinal canal stenosis at different levels are observed. Cervical pathology is less frequent in type I than in types IV and VI. Hypoplasia of the odontoid process, ${ }^{25}$ in some cases, associated with atlantoaxial cervical instability, is detected in the cervical radiographic pair, in maximum flexion and extension.

Progressive kyphoscoliosis leads to decompensation of the trunk, instability, and potential neurological compromise. ${ }^{28,29}$ Patients range from being asymptomatic to presenting neurological involvement secondary to spinal cord compression. ${ }^{30,31}$

Out of the 42 operated patients (assisted at Hospital Garrahan) with mucopolysaccharidosis of different types (IV, VI, and I), $55 \%$ had neurological involvement. Twenty five percent had odontoid hypoplasia; $21 \%$, atlantoaxial instability; and $21 \%$, narrowing of the cervical spinal canal due to glycosaminoglycan deposits.

If cervical stenosis is suspected at the time of the clinical examination, radiographic studies, static magnetic resonance and preoperative CT scans should be performed. A specialized assessment is required. ${ }^{32}$ Somatosensory and motor evoked potentials, sometimes urodynamic testing and polysomnographic evaluations are also performed.

Surgery is performed by releasing compressions and preserving the neurological structures, using subsequent decompression techniques, mostly associated with arthrodesis. ${ }^{32}$ Prophylactic versus therapeutic fusions are controversial. Surgery should be done at an early stage when indicated. ${ }^{33}$

The most frequent deformity is kyphosis with apex at the L1 or L2 region, followed by scoliosis, or combined. In children under 7 years of age with kyphoscoliosis and curves with an angle of less than 50 degrees, a custom-made thermoplastic thoracolumbosacral orthosis is used, 22 hours per day, which allows practising physical activity or sports if there is no spinal risk at the cervical or thoracolumbar level. For older ages, with curves between 50 and 70 degrees or more, instrumental fusions are indicated at a later stage. With a deformity associated with spinal stenosis and neurological deficit, a double approach is used (anterior decompression and arthrodesis + posterior instrumental fusion). The surgical team includes highly qualified anesthesiologist and neurophysiologist.

\section{Neurological manifestations}

MPS I has a progressive involvement of the central (CNS) and peripheral nervous systems (PNS), which varies according to the clinical form. 
They include cognitive impairment, behavioral problems, sleep disorders, hydrocephalus and spinal cord compression; root, peripheral nerve and cranial nerve entrapment.

\section{Cognitive impairment}

In the SF, after a period of normal development, a stagnation occurs between the first and second year of life, followed by a fast cognitive deterioration. ${ }^{34-36}$ Approximately 20 intellectual quotient (IQ) points are lost per year. ${ }^{37}$ Neurodegeneration involves heparan sulfate deposit, which acts as a matrix of neuroinflammation and overexpression of gangliosides with a neurotoxic effect, which induces ectopic dendritogenesis and abnormal synaptogenesis. ${ }^{38}$

The AFs are not entirely free of cognitive developmental problems. For every year that treatment is delayed, there will be 9 IQ points less. ${ }^{39}$ Some mutations (L238Q) favor late psychiatric manifestations, such as self-isolation and depression. ${ }^{40}$

There are no biomarkers to determine the presence of neurodegeneration. This is measured by formal cognitive assessment over time. Up to age 3 , it is recommended to use the Bayley-III scale, which provides age-equivalent scores. For those over 3 years old, IQ can be measured with the Wechsler scales. For the adaptive behavior, the Vineland scale is recommended for all ages. ${ }^{34}$

Early hearing impairment can, per se, affect language. New functional neuroimaging and their correlation with higher mental functions are still being studied. ${ }^{41}$ For a better long-term cognitive prognosis in the SFs, early transplantation should be indicated. ${ }^{42}$

\section{Hydrocephalus}

Hydrocephalus is a relatively frequent complication in mucopolysaccharidoses, especially in MPS I and II, and, together with glycosaminoglycan deposits in the different planes, it contributes to macrocephalus. It presents with slow neurological disorders, progressive deterioration, and rarely, papilledema, headache, and vomiting.

From $80 \%$ to $85 \%$ of cases are communicating. ${ }^{43}$ The dynamics of cerebrospinal fluid (CSF) circulation is altered by glycosaminoglycan deposit with obstruction of the subarachnoid spaces and Pacchionian granulations, with reduction of the venous drainage.
In children, it is corrected when required, with ventriculoperitoneal, ventriculoatrial or lumboperitoneal shunts to shorten the subcutaneous path. The accumulation of glycosaminoglycans can predispose to blockage of the shunt.

Glycosaminoglycan deposits in the white matter and basal ganglia promotes tissue destruction, compression of the parenchymal vessels, dilation of the perivascular and subarachnoid spaces, which leads to cerebral atrophy with passive dilation of the ventricles and mimics hydrocephalus. This one does not require treatment.

\section{Spinal cord compression}

Glycosaminoglycan deposits in the dura mater and ligaments causes spinal cord compression and myelopathy. Early detection and surgical correction prevents irreversible damage of the spinal cord. Initial, mild, insidious signs (progressive weakness, clumsiness, fatigue, hyperreflexia, pain, and paresthesias) may be confused with signs of osteoarticular diseases. ${ }^{37,38}$

\section{Diagnosis}

It is performed by showing in the patient with suggestive signs and symptoms, the deficiency of the enzyme alpha-L-iduronidase in purified leukocytes or blood drops on filter paper. Newborn screening can also be performed. ${ }^{1,8,9}$

The methods available today make it unnecessary to measure enzyme activity in fibroblast culture. Table 2 shows the advantages and limitations of the available biochemical methods. The molecular study is not essential for diagnosis, but it is necessary to indicate the treatment.

\section{Available treatments}

The specific treatments are allogeneic hematopoietic stem cell transplantation (HSCT) or enzyme replacement therapy (ERT). The European consensus forwards the treatment decisionmaking to a team of experts, which is an excellent recommendation to be applied in our setting. ${ }^{44}$

HSCT is the treatment of choice for the SF to replace the defective monocytic-macrophage system with that of the donor, which secretes the missing enzyme. Offered at $<2$ years and with an $\mathrm{IQ}>70$, it can stop progressive neurocognitive deterioration and damage to other organs. ${ }^{8,44}$ Those older than 2 years and with IQ $<70$ have poor benefit from HSCT. 
Age is the most important outcome measure. By transplanting before 12 months of age, the best cognitive prognosis is achieved and, before 9 months, the neurocognitive development achieved may be normal. ${ }^{42,45-48}$

Since the first HSCT performed in 1981 to date, more than 500 patients have been transplanted. In Argentina, between 2009 and 2018, 17 patients underwent $20 \mathrm{HSCT}^{*}$ ( ${ }^{*}$ data provided by the National Institute for Organ and Tissue Procurement for Transplantation [Instituto Nacional Central Único Coordinador de Ablación e Implante, INCUCAI]).
About $25 \%$ will have a related donor; the rest will require an international registry search.

There may be a graft loss of up to $30 \%$, but busulfan-based myeloablative conditioning has improved this figure. With the busulfan/ fludarabine regimen, survivals $>90 \%$ have been reported. ${ }^{42,44,45,49}$

Five-year overall survival (OS) rate ranges from $74 \%$ to $95 \%$, and event-free survival from $63 \%$ to $90 \%$, depending on the type of donor and the sources of hematopoyetic stem cells used for the transplantation. ${ }^{46,47}$ Transplant-related

TABLE 2. Diagnostic methods

\begin{tabular}{|c|c|c|c|}
\hline \multicolumn{2}{|c|}{ Type of sample } & \multicolumn{2}{|l|}{ Advantages } \\
\hline \multicolumn{4}{|c|}{ Glycosaminoglycans in urine } \\
\hline $\begin{array}{l}\text { Quantitative } \\
\text { Glycosaminoglycan } \\
\text { concentration in } \\
\text { urine measured } \\
\text { and corrected } \\
\text { to urinary } \\
\text { creatinine levels. }\end{array}$ & $\begin{array}{l}\text { - 24-hour } \\
\text { urine test }\end{array}$ & $\begin{array}{l}\text { - It is useful as a screening } \\
\text { method for those } \\
\text { mucopolysaccharidoses } \\
\text { with high } \\
\text { glycosaminoglycan } \\
\text { levels in urine. } \\
\text { - The test can be used to } \\
\text { monitor the course of the disease or } \\
\text { the response to treatment. }\end{array}$ & $\begin{array}{l}\text { - Non-specific for heparan and dermatan sulfate. } \\
\text { - Some patients may excrete normal or slightly } \\
\text { increased amounts of glycosaminoglycans. } \\
\text { - Cut-off levels should be set according to the } \\
\text { patient's age. Glycosaminoglycan concentration } \\
\text { decreases as the patient's age increases. } \\
\text { - Results can be false positive if urine has a } \\
\text { high creatinine level or negative if urine is very diluted. } \\
\text { - The sample is difficult to obtain in patients who do not have } \\
\text { sphincter control (young children or those with mental retardation). } \\
\text { - Sample delivery to a referral center. } \\
\text { - A negative test may result in a patient not being studied further. }\end{array}$ \\
\hline \multicolumn{4}{|l|}{ Qualitative } \\
\hline $\begin{array}{l}\text { It specifically } \\
\text { identifies the type of } \\
\text { glycosaminoglycans } \\
\text { present in the urine, } \\
\text { which allows } \\
\text { classifying the type of } \\
\text { mucopolysaccharidosis } \\
\text { the patient may have. }\end{array}$ & $\begin{array}{l}\text { - 24-hour } \\
\text { urine test }\end{array}$ & $\begin{array}{l}\text { - A specific pattern of } \\
\text { excretion can be observed } \\
\text { or different } \\
\text { mucopolysaccharidoses } \\
\text { even in cases where } \\
\text { glycosaminoglycan } \\
\text { quantification was normal. }\end{array}$ & $\begin{array}{l}\text { - The profile obtained does not allow to tell the } \\
\text { difference between MPS I and II. } \\
\text { - The sample is difficult to obtain in patients } \\
\text { who do not have sphincter control } \\
\text { (young children or those with mental retardation). } \\
\text { - A specialized laboratory is required to perform this assay. }\end{array}$ \\
\hline
\end{tabular}

the patient may have.

Alpha-L-iduronidase enzyme activity assay

\begin{tabular}{|c|c|c|c|}
\hline Leukocytes & $\begin{array}{l}\text { - } 10 \mathrm{~mL} \text { of } \\
\text { heparinized } \\
\text { blood. }\end{array}$ & $\begin{array}{l}\text { - Highly sensitive and specific method. } \\
\text { - Once the sample is conditioned, } \\
\text { it can be stored for a long time. }\end{array}$ & $\begin{array}{l}\text { - The sample must be delivered at the laboratory within } \\
24 \text { hours of being obtained. } \\
\text { - The required sample volume is high, especially in } \\
\text { pediatric patients. } \\
\text { - A specialized laboratory is required to perform this assay. }\end{array}$ \\
\hline Fibroblasts & • Skin biopsy. & $\begin{array}{l}\text { - Multiple assays can be performed } \\
\text { in the same specimen. } \\
\text { - Once the sample is conditioned, } \\
\text { it can be stored for a long time. }\end{array}$ & $\begin{array}{l}\text { - Invasive specimen collection method. } \\
\text { - The development of the fibroblast culture requires weeks } \\
\text { to be able to do the enzyme assay, which delays the result. } \\
\text { - Transportation might affect the sample. } \\
\text { - A specialized laboratory is required to perform this assay. }\end{array}$ \\
\hline BDFP & $\begin{array}{l}\text { - Filter paper } \\
\text { soaked in whole } \\
\text { blood (the same } \\
\text { that is used for } \\
\text { newborn } \\
\text { screening). }\end{array}$ & $\begin{array}{l}\text { - Minimally-invasive sample collection. } \\
\text { - Easy transportation. } \\
\text { - Multiple assays can be performed } \\
\text { in the same specimen. } \\
\text { - Allows for large-scale testing. } \\
\text { - Good correlation of results } \\
\text { obtained in leukocytes. }\end{array}$ & $\begin{array}{l}\text { - A specialized laboratory is required to perform this assay. } \\
\text { - Results obtained should be confirmed in } \\
\text { leukocytes or by genetic testing. }\end{array}$ \\
\hline
\end{tabular}


mortality ranges from $10 \%$ to $25 \%$, mainly due to viral infectious causes, graft versus host disease (GVHD), pulmonary complications, bleeding, and multiple organ failure. ${ }^{46,49}$

Cord blood (CB) stem cells have been shown to be more likely to achieve donor chimerism $(p=0.39)$ and normal enzyme levels $(p=0.07)(92 \%$ and $98 \%$, respectively) compared to other sources. OS with $\mathrm{CB}$ (identity $6 / 6$ ), of $81 \%$, is comparable to the related identical donor transplantation. It would be a preferential source because of the rapid availability and larger population of primitive hematopoietic stem cells. The period of aplasia is longer, with the consequent higher risk of viral reactivations, and only one donation per donor is feasible. Results obtained with CB (OS 90 \%) are better than those obtained with bone marrow or peripheral blood stem cells. They could be influenced by supportive care, conditioning, and high degree of compatibility since they are from the last decade. ${ }^{45-47,49}$

Options for a HSCT would be as follows:

1. Related identical donor (sibling, with molecular studies).

2. Unrelated donor (URD) $10 / 10$ or CB $6 / 6$ (high-resolution human leukocyte antigen, HLA).

Enzyme activity reaches values comparable to those of the donor in the first 3 months. Approximately $50 \%$ of the normal value is achieved with a carrier donor and $100 \%$ with an unaffected donor. ${ }^{49}$

Compromise of some organs might persist depending on the previous disease burden. Hepatosplenomegaly, ventilatory symptoms, and myocardial hypertrophy improve, although valve alterations may persist. Corneal opacity improves, but retinal degeneration may occur. Hearing also improves, even though a neurosensorial component may be present.

Short stature will remain. Skeletal dysplasia persists. It improves odontoid dysplasia and cervical stability, joint mobility of the upper limbs, more than that of the lower limbs. There may be delayed puberty and reduced fertility. ${ }^{42,43,46}$ Cognitive impairment improves 6-12 months after transplantation because it requires the presence of donor macrophages transporting microglial enzymes and the replacement turnover rate is slow. ${ }^{42,45,49,50}$

Long-term prognosis of a HSCT depends on age, baseline clinical status, and complete chimerism. Early diagnosis, timely referral, and rapid admission to experienced transplant centers are critical. ${ }^{42,45,49,50}$ Follow-up should be done by a multidisciplinary and interdisciplinary team, with active participation of the transplant team during, at least, 1 year.

ERT with recombinant human laronidase is for AFs, not for SFs, because it does not cross the blood-brain barrier (BBB). ${ }^{45}$ The best treatment outcome depends on age, severity, and each patient's degree and type of clinical compromise. ${ }^{45}$

With a HSCT, compared to an ERT, a better metabolic control is obtained. ${ }^{51}$ It does not improve CNS, bone, heart valves or corneal conditions. Pre-transplant ERT improves respiratory function and cardiomyopathy. It does not increase the risk for developing immunemediated reactions nor it negatively affects the graft nor promotes GVHD. An improvement of cognitive functions was reported in relation to post-transplant ERT, probably because of the improvement of the other clinical manifestations. ${ }^{52}$

ERT modifies the natural history of the disease in the AFs, improves hepatosplenomegaly, skin thickness, respiratory function, and cardiomyopathy, but does not reverse the abnormal range of the already established joint mobility problems and conditions, such as dysostosis, valve disease, and corneal opacity. Early ERT in the AFs, before the establishment of the inflammatory cascade after the glycosaminoglycan deposit, prevents the occurrence of some of these manifestations. The indication differs, then, from the criteria established in 2008 to treat the AFs. ${ }^{1}$ The sooner it starts, the better.

A better course was reported with the 12 year follow-up of a patient who was administered ERT at 5 months old, compared to his sister who started treatment at 5 years old. The younger brother maintained normal facies and fewer skeletal, joint, and myocardial lesions; he was in the $97^{\text {th }}$ percentile, and his sister in the $10^{\text {th }}$ percentile, and reached an IQ of 100, while his sister reached $70 .{ }^{53}$ ERT benefit appears minimal in non-transplanted patients with SFs. ${ }^{54}$ It is suggested that a group of experts should evaluate this indication on an individual basis. ${ }^{55}$

\section{CONCLUSIONS}

Early diagnosis and treatment modify the course of the disease. Ideally, an interdisciplinary team should be in charge of the follow-up. 


\section{REFERENCES}

1. Grupo de trabajo de enfermedades poco frecuentes. Consenso de diagnóstico y tratamiento de la mucopolisacaridosis tipo I. Arch Argent Pediatr. 2008; 106(4):361-8.

2. ClarkeLA, Giugliani R, Guffon N, JonesSA, etal. Genotype $\square$ phenotype relationships in mucopolysaccharidosis type I (MPS I): Insights from the International MPS I Registry. Clin Genet. 2019; 96(4):281-9.

3. Izumi $Y$, Saito T, Sato S, Shimizu W. Myocardial Alterations in a Patient with Mucopolysaccharidosis Type I. Eur Heart J. 2018; 39(21):1863.

4. Soliman OI, Timmermans RG, Nemes A, Vletter WB, et al. Cardiac abnormalities in adults with the attenuated form of mucopolysaccharidosis type I. J Inherit Metab DisCardiac abnormalities in adults with the attenuated form of mucopolysaccharidosis type I. J Inherit Metab Dis. 2007; 30(5):750-7.

5. Watanabe N, Anagnostopoulos PV, Azakie A. Aortic stenosis in a patient with Hurler's syndrome after bone marrow transplantation. Cardiol Young. 2011; 21(3):349-50.

6. Robinson CR, Roberts WC. Outcome of Combined Mitral and Aortic Valve Replacement in Adults with Mucopolysaccharidosis (the Hurler Syndrome). Am J Cardiol. 2017; 120(11):2113-8.

7. Dangel JH. Cardiovascular Changes in Children with Mucopolysaccharide Storage Diseases and Related Disorders-Clinical and Echocardiographic Findings in 64 Patients. Eur J Pediatr. 1998; 157(7):534-8.

8. Muenzer J, Wraith E, Clarke LA. Mucopolysaccharidosis I: management and treatment guidelines. Pediatrics. 2009; 123(1):19-29.

9. Martins AM. Introduction to Brazilian Guidelines to diagnosis, treatment, and monitoring for Gaucher disease, Fabry disease, Mucopolysaccharidosis I, and Pompe disease. J Pediatr. 2009; 155(4 Suppl):S9.

10. Muñoz-Rojas MV, Bay L, Sanchez L, Van KuijckM, et al. Clinical manifestations and treatment of mucopolysaccharidosis type i patients in Latina America as compared with the rest of the world. J Inherit Metab Dis. 2011; 34(5):1029-37.

11. Kelly AS, Metzig AM, Steinberger J, Braunlin EA. Endothelial function in children and adolescents with mucopolysaccharidosis. I Inherit Metab Dis. 2013; 36(2):221-5.

12. Wang R Y, Rudser KD, Dengel DR, Braunlin EA, et al. The Carotid Intima-Media Thickness and Arterial Stiffness of Pediatric Mucopolysaccharidosis Patients are Increased Compared to Both Pediatric and Adult Controls. Int J Mol Sci. $2017 ; 18(3): 637$.

13. LealGN, DePaula AC, Leone C, Kim CA. Echocardiographic study of paediatric patients with mucopolysaccharidosis. Cardiol Young. 2010; 20(3):254-61.

14. Moretto A, Bosatra MG, Marchesini L, Tesoro S. Anesthesiological risks in mucopolysaccharidoses. Ital $\mathrm{J}$ Pediatr. 2018; 44(Suppl 2):116.

15. Solaiman SS, Rifkin DS, Rao H. Sleep Apnea in Hurler Syndrome: Looking Beyond the Upper Airway. J Clin Sleep Med. 2016; 12(10):1423-4.

16. Wooten WI 3rd, Muenzer J, Vaughn BV, Muhlebach MS. Relationship of Sleep to Pulmonary Function in Mucopolysaccharidosis II. J Pediatr. 2013; 162(6):1210-5.

17. Semenza GL, Pyeritz RE. Respiratory complications of mucopolysaccharidestorage disorders. Medicine(Baltimore). 1988; 67(4):209-19.

18. Marcus CL. Sleep-disordered breathing in children. Am J Respir Crit Care Med. 2001; 164(1):16-30.

19. Bush D, Sremba L, Lomax K, Lipsett J, et al. Neonatal Onset
InterstitialLungDiseaseasaPrimary Presenting Manifestation of Mucopolysaccharidosis Type I. JIMD Rep. 2019; 43:71-7.

20. Allen JL. Treatment of respiratory system (not just lung!) abnormalities in mucopolysaccharidosis I. J Pediatr. 2004; 144(5):561-2.

21. Shinhar SY, Zablocki H, Madgy DN. Airway management in mucopolysaccharide storage disorders. Arch Otolaryngol Head Neck Surg. 2004; 130(2):233-7.

22. Gökdoğan Ç, Altinyay Ş, Gökdoğan O, Tutar H, et al. Audiologic evaluations of children with mucopolysaccharidosis. Braz J Otorhinolaryngol. 2016; 82(3):281-4.

23. White KK. Orthopaedic aspects of mucopolysaccharidoses. Rheumatology (Oxford). 2011; 50(Suppl 5):v26-33.

24. Field RE, Buchanan JAF, Copplemans MGJ, Aichroth PM. Bone marrow transplantation in Hurlers syndrome: effect on skeletal development. JBone Joint Surg Br. 1994;76(6):97581.

25. Langer L Jr, Carey L. The roentgenographic features of the KS mucopolysaccharidosis of Morquio (MorquioBrailsford's disease). Am J Roentgenol Radium Ther Nucl Med. 1966; 97(1):1-20.

26. Swischuk LE. The beaked, notched, or hooked vertebra: Its significance in infants and young children. Radiology. 1970; 95(3):661-4.

27. Tandon V, Williamson JB, Cowie RA, Wraith JE. Spinal problems in mucopolysaccharidosis I (Hurler syndrome). J Bone Joint Surg Br. 1996; 78(6):938-44.

28. Holte DC, Rogers MA, Ransford AO, Crockard HA, et al. Thoracic spinal cord compression in Morquio-Brailsford's disease: Report of a case and review of the literature. NeuroOrthopaedics. 1994; 16:31-7.

29. Kulkarni MV, Williams JC, Yeakley JW, Andrews JL, et al. Magnetic resonance imaging in the diagnosis of the craniocervical manifestations of the mucopolysaccharidoses. Magn Reson Imaging. 1987; 5(5):317-23.

30. Hughes DG, Chadderton RD, Cowie RA, Wraith JE, et al. MRI of the brain and craniocervical junction in Morquio's disease. Neuroradiology. 1997; 39(5):381-5.

31. Ransford A, Crockard H, Stevens J, Modaghegh S. Occipitoatlanto-axial fusion in Morquio-Brailsford Syndrome. J Bone Joint Surg Br. 1996; 78(2):307-13.

32. KachurE, Del Maestro R. Mucopolysaccharidosis and spinal cord compression: case report and review of the literature with implications of bone marrow transplantation. Neurosurgery. 2000; 47(1):223-9.

33. Sostrin RD, Hasso AN, Peterson DI, Thompson JR. Myelographic features of mucopolysaccharidosis: a new sign. Radiology. 1977; 125(2):421-4.

34. Shapiro EG, Escolar ML, Delaney KA, Mitchell JJ. Assessments of neurocognitive and behavioral function in the mucopolysaccharidoses. Mol Genet Metab. 2017; 122(Suppl:8)-16.

35. Shapiro EG, Nestrasil I, Rudser K, Delaney $K$, et al. Neurocognition across the spectrum of mucopolysaccharidosis type I: age, severity, and treatment. Mol Genet Metab. 2015; 116(1-2):61-8.

36. KrivitW,Peters C, ShapiroEG. Bonemarrow transplantation as effective treatment of central nervous system disease in globoid cell leukodystrophy, metachromatic leukodystrophy, adrenoleukodystrophy, mannosidosis, fucosidosis, aspartylglucosaminuria, Hurler, MaroteauxLamy and Sly syndromes, and Gaucher disease type III. Curr Opin Neurol. 1999; v12(2):167-76.

37. Krenzlin H, Ta-Chih T, Lampe C, Knuf M, et al. Standalone craniocervical decompression is feasible in children with MPS type I, IVA and VI. Spine J. 2018; 18(8):1455-9.

38. Vitner EB, Platt FM, Futerman AH. Common and 
uncommon pathogenic cascades in lysosomal storage diseases. J Biol Chem. 2010; 285(27):20423-7.

39. Van der Lee JH, Morton J, Adams HR, Clarke L, et al. Cognitive endpoints for therapy development for neuronopathic mucopolysaccharidoses: results of a consensus procedure. Mol Genet Metab. 2017; 121(2):70-9.

40. Ahmed A, Whitley CB, Cooksley R, Rudser K, et al. Neurocognitive and neuropsychiatric phenotypes associated with the mutation L238Q of the $\alpha$-L-iduronidase gene in Hurler-Scheie syndrome. Mol Genet Metab. 2014; 111(2):123-7.

41. Shapiro EG. Longitudinal studies of brain structure and function in MPS disorders: a study of the lysosomal disease network. Mol Genet Metab. 2010; 99(2)s34.

42. Parini R, Deodato F, Di Rocco M, Lanino E, et al. Open Issues in Mucopolysaccharidosis type I-Hurler. Orphanet J Rare Dis. 2017; 12(1):112.

43. Aldenhoven M, Wynn R, Orchard P, O'Meara A, et al. Long-term outcome of Hurler Syndrome patients after hematopoietic cell transplantation: an international multicenter study. Blood. 2015; 125(13):2164-72.

44. Martins AM, Dualibi AP, Norato D, Takata ET, et al. Guidelines for the Management of Mucopolysaccharidosis Type I. J Pediatr. 2009; 155(4 Suppl):S32-46.

45. De Ru MH, Boelens JJ, Das AM, Jones SA, et al. Enzyme replacement therapy and/or hematopoietic stem cell transplantation at diagnosis in patients with mucopolysaccharidosis type I: results of a European consensus procedure. Orphanet J Rare Dis. 2011; 6:55.

46. Boelens JJ, Prasad VK, Tolar J, Wynn RF, et al. Current international perspectives on hematopoietic stem cell transplantation for inherited metabolic disorders. Pediatr Clin North Am. 2010; 57(1):123-45.
47. Aldenhoven M, Jones S, Bonney D, Borrill RE, et al. Hematopoietic cell transplantation for Mucopolysaccharidosis patients is safe and effective: Results after implementation of international Guidelines. Biol Marrow Transplant. 2015; 21(6)1106-9.

48. Boelens JJ, Aldenhoven M, Purtill D, Ruggeri A, et al. Outcomes of transplantation using various hematopoietic cell sources in children with Hurler syndrome after myeloablative conditioning. Blood. 2013; 121(19):3981-7.

49. Poe MD, Chagnon SL, Escolar ML. Early treatment is associated with improved cognition in Hurler syndrome. Ann Neurol. 2014; 76(5):747-53.

50. Aldenhoven M, Boelens JJ, De Koning T. The clinical outcome of Hurler syndrome after stem cell transplantation. Biol Blood Marrow Transplant. 2008; 14(5):485-98.

51. Wynn RF, Wraith JE, Mercer J, O'Meara A, et al. Improved metabolic correction in patients with lysosomal storage disease treated with hematopoietic stem cell transplant compared with enzyme replacement therapy. J Pediatr. 2009; 154(4):609-11.

52. Eisengart JB, Rudser KD, Tolar J, Orchard PJ, et al. Enzyme replacement is associated with better cognitive outcomes after transplant in Hurler syndrome. J Pediatr. 2013; 162(2):375-80.e1.

53. Gabrielli O, Clarke LA, Ficcadenti A, Santoro L, et al. 12 year follow up of enzyme-replacement therapy in two siblings with attenuated mucopolysaccharidosis I: the important role of early treatment. BMC Med Genet. 2016; 17:19.

54. Yano S, Moseley K, Pavlova Z. Postmortem studies on a patient with mucopolysaccharidosis type I: histopathological findings after one year of enzyme replacement therapy. J Inherit Metab Dis. 2009; 32(Suppl 1):S53-7.

55. Pasad VK, Kurtzberg J. Transplant outcome in mucopolysaccharidoses. Semin Hematol. 2010; 47(1):59-69. 